\title{
Persistence of Azoxystrobin in/on Grapes and Soil in Different Grapes Growing Areas of India
}

\author{
Vijay Tularam Gajbhiye $\cdot$ Suman Gupta $\cdot$ \\ Irani Mukherjee - Shashi Bala Singh • \\ Neera Singh $\cdot$ Prem Dureja $\cdot$ Yogesh Kumar
}

Received: 19 August 2010/Accepted: 29 November 2010/Published online: 14 December 2010

(C) The Author(s) 2010. This article is published with open access at Springerlink.com

\begin{abstract}
Persistence of azoxystrobin was studied in/on grapes when applied @ $150 \mathrm{~g} \mathrm{ai} \mathrm{ha}^{-1}$ (recommended dose) and $300 \mathrm{~g}$ ai ha ${ }^{-1}$ (double the recommended dose) in three grapes growing states of India, namely Karnataka, Maharashtra and Tamil Nadu, in the year 2006-2007. A total of five sprays were given at an interval of about 15 days. Grapes and soil samples were collected after 5th spray, extracted and analysed by gas chromatography using electron capture detector. Half life of azoxystrobin on grapes varied from 5.4 to 11.2 days. Residues of azoxystrobin were much below the prescribed MRL $\left(0.5 \mathrm{mg} \mathrm{kg}^{-1}\right)$ after 21 days. The dissipation of azoxystrobin in soil followed first order rate kinetics with an average half life of 8.1 days at the recommended dose of application.
\end{abstract}

Keywords Azoxystrobin · Persistence $\cdot$ Grapes - Soil

\section{Introduction}

In India, grape is one of the most important fruit crop covering an area of 60.2 thousand hectares with total production of 1,546 thousand metric tonnes. The major grapes growing states in India are Maharashtra, Karnataka, Andhra Pradesh, Tamil Nadu, Punjab, Haryana, Western Uttar Pradesh, Rajasthan and Madhya Pradesh. India is also

V. T. Gajbhiye $\cdot$ S. Gupta $\cdot$ I. Mukherjee

S. B. Singh · N. Singh · P. Dureja $(\bowtie)$

Division of Agricultural Chemicals, Indian Agricultural

Research Institute, New Delhi 110 012, India

e-mail: pd_dureja@yahoo.com

Y. Kumar

Rallis India Limited, Bangalore, India exporting grapes to more than 50 countries. (Anonymous 2009).

Grapes are attacked by a number of fungal diseases such as anthracnose (Elsinoe ampelina), downy mildew (Plasmopara viticola), powdery mildew (Uncinula necator), botrytis rot/grey mould (Botrytis cinerea), dead arm (Phomopsis viticola), black rot (Guignardia bidwelli), rust (Phakopsora vitis), leaf blight and bunch necrosis (Alternaria alternata), bacterial leaf spot (Xanthomonas campestris), etc., which spoil the quality and yield of grapes (Pearson and Goheen 1994; Sendhilvel et al. 2004). To control these diseases fungicides such as triadimefon, chlorothalonil, Topsin-M, benomyl, calaxin, mancozeb, metalaxyl, and sulphur dusting are recommended (APEDA 2009). These fungicides are persistent and leave residue on the grapes; therefore, a number of consignments are rejected suggesting a need for low dosage, safe and biodegradable fungicides.

In this paper we report the persistence of azoxystrobin (methyl (E)-2-\{2-[6-(2-cyanophenoxy) pyrimidin-4-yloxy] phenyl \}-3-methoxyacrylate), a new synthetic biodegradable strobilurin fungicide launched by Syngenta India Ltd. It was first marketed in 1998 and is a systemic, broad-spectrum fungicide with activity against the four major groups of plant pathogenic fungi including Ascomcetes (e.g., powdery mildews), Basidiomycetes (e.g., rusts), Deutoromycetes (e.g., rice blast) and Oomycetes (e.g., downy mildew) (Bartlett et al. 2002; Anand et al. 2008). It is absorbed through the roots and translocated in the xylem to the stems and leaves, or through leaf surfaces to the leaf tips and growing edges. The mode of action is by inhibition of mitochondrial respiration in fungi. It inhibits spore germination, mycelial growth, and spore production of fungi. It is active at very low doses against a wide range of fungal pathogens. Laboratory studies show that azoxystrobin is moderately persistent in soil in the 
absence of light and moderately mobile in soil profile. It has been reported that in field trials azoxystrobin on grapes disappeared quite slowly $\left(\mathrm{t}_{1 / 2}=15.2\right.$ days) (Cabras et al. 1998; Cabras and Angioni 2000; Lentzarizos et al. 2006). It is more persistent in the aerobic soil than the anaerobic soil with half-life values of 107.47 and 62.69 days, respectively. As there is not much information available on the persistence of azoxystrobin in crop plants, especially under tropical climate, therefore, the present investigation on persistence of azoxystrobin was studied in/on grapes in different states of India namely Karnataka, Maharashtra and Tamil Nadu, during the year 2006-2007.

\section{Materials and Methods}

Azoxystrobin (96.2\% purity) and its formulation (SC $250 \mathrm{~g} \mathrm{~L}^{-1}$ ) were provided by Rallis India Ltd. The analytical grade solvents were procured locally.

The field experiments were conducted on farmer's field in Maharashtra, Karnataka and Tamil Nadu, India. Details of location and crops are given in Table 1. All the experiments were conducted in a randomized block design with three replications, with ten vines in each field. All the agronomic practices except plant protection measures were followed. The crops were sprayed with azoxystrobin@ @ $150 \mathrm{~g}$ ai ha ${ }^{-1}$ (recommended dose) and $300 \mathrm{~g}^{\text {ai ha }}{ }^{-1}$ (double the recommended dose) five times at an interval of 15 days from the starting stage ( $\sim 2$ months after pruning) with a high volume knapsack sprayer. No other crop protection measure was used in the experimental plots. Fields without application of azoxystrobin were treated as control.

The samples of grape berries and soils from the treated plots were withdrawn at different time intervals after 5 th spray (0 (2 h), 3, 7, 14 and 21 day). The representative samples of grape berries plucked from 4 to 5 vines from each plot were pooled and mixed well and $200 \mathrm{~g}$ of the sample was withdrawn by quartering method for analysis. Soil samples were withdrawn from the treated plots using soil auger from the plough layer $(15 \mathrm{~cm})$ from 5 to 6 places. The soil samples were pooled, mixed well and about $250 \mathrm{~g}$ of the representative sample was drawn by quartering method and were packed in dry ice. Before extraction the samples were removed from dry ice and allowed to attain room temperature. The soil samples were dried at room temperature under shade, ground, passed through $2 \mathrm{~mm}$ sieve and a representative $20 \mathrm{~g}$ sample was taken for analysis. Similarly, a representative $50 \mathrm{~g}$ sample of grape berries was drawn by quartering method for residue analysis.

Twenty gram of the withdrawn soil sample was shaken with acetone in a rotary shaker at $160 \mathrm{rpm}$ for $30 \mathrm{~min}$ and was further allowed to remain with the extraction solvent for $1 \mathrm{~h}$. The supernatant was passed through anhydrous sodium sulphate column. The extraction was repeated twice again with $25 \mathrm{~mL}$ portions of acetone. The organic solvent fractions from these extractions were combined and the solvent was removed by using rotary flash evaporator. The residue was re-dissolved in hexane and analyzed by gas liquid chromatography (GLC).

A representative $50 \mathrm{~g}$ sample of grape berries was blended with $50 \mathrm{~mL}$ (three times) acetone in a blender and filtered through Whatman filter paper No.1. The acetone extract was evaporated to near dryness $(5 \mathrm{~mL})$ using rotary vacuum evaporator and diluted with $50 \mathrm{~mL}$ of saturated sodium chloride solution and partitioned thrice into hexane $(3 \times 50 \mathrm{~mL})$. Hexane layer was discarded and lower aqueous layer was partitioned with dichloromethane $(3 \times 50 \mathrm{~mL})$. The dichloromethane fractions were combined and passed through anhydrous sodium sulfate and the solvent was removed by using rotary flash evaporator.

The co-extractives from grape and soil samples were removed by adsorption column chromatography using neutral alumina as adsorbent. Glass column $(50 \times 2.5 \mathrm{~cm}$ i.d.) was packed with a slurry of neutral alumina (10 g) in n-hexane, in between two 2-cm layers of anhydrous sodium sulfate. The packed column was eluted with $50 \mathrm{~mL}$ of distilled n-hexane. The concentrated dichloromethane extracts of soil and grape berries were quantitatively transferred on to the column using small portions of n-hexane. The column was first eluted with a mixture of acetone: hexane $(95: 5 \mathrm{v} / \mathrm{v}, 50 \mathrm{~mL})$ to remove the non polar impurities and then eluted with acetone:hexane (80:20 v/v, $150 \mathrm{~mL})$. Fractions obtained by eluting column with acetone:hexane $(80: 20 \mathrm{v} / \mathrm{v})$ were combined and solvent was removed by rotary evaporator. The residue was dissolved in acetone and analysed by GLC.

Table 1 Experimental details of three grapes growing locations selected for the study in India

\begin{tabular}{llll}
\hline Detail & Maharashtra & Karnataka & Tamil Nadu \\
\hline Place & Songaon, Baramati Dist. Pune & Singanayakanahalli, Bangalore & Mattipalya, Sonnanur, Coimbatore \\
Season & January-March & September-November & September-October \\
Variety & Thomson seedless & Bangalore blue & Mascot \\
Soil & Medium to heavy & Sandy loam & Sandy loam \\
\hline
\end{tabular}


The samples were analyzed on a Varian CP-3800 gas chromatograph equipped with electron capture detector (ECD) and CP-Sil $5 \mathrm{CB}$ capillary column $(25 \mathrm{~m} \times$ $0.25 \mathrm{~mm}$ id $\times 0.25 \mu \mathrm{m}$ film thickness). The oven, injector and detector temperatures were maintained at 290, 300 and $300^{\circ} \mathrm{C}$, respectively, and the flow rate of the carrier gas (nitrogen) was maintained at $2 \mathrm{~mL} \mathrm{~min}^{-1}$. The injection volume was $1.0 \mu \mathrm{L}$ with spit ratio of $1: 50$. The retention time for azoxystrobin under above GLC condition was $2.98 \mathrm{~min}$.

The residue data was subjected to first order kinetics $\left(C_{t}=C_{o} e^{-k t}\right)$, where $C_{t}$ is concentration after a lapse of time ' $\mathrm{t}$ '; $\mathrm{C}_{0}$ is apparent initial concentration and ' $\mathrm{k}$ ' is the dissipation constant. Half-life values were calculated from regression equation using the formula $\left(\mathrm{T}_{1 / 2}=0.693 / \mathrm{K}\right)$ and waiting period $\left(\mathrm{T}_{\mathrm{tol}}\right)$ from regression equation $\left(\mathrm{T}_{\text {tol }}=\left(\log \mathrm{C}_{0}-\log \mathrm{C}_{\mathrm{t}}\right) / \mathrm{K}\right)$.

\section{Results and Discussion}

The grape berries and soil samples collected at different time intervals after 5th spray were analysed for the presence of residues of azoxystrobin by gas liquid chromatography using electron capture detector.

A gas liquid chromatography method for analysis of azoxystrobin in soil and grape samples was standardised using electron capture detector with response factor of $4,618,500 \mu \mathrm{V}$ per $\mu \mathrm{g}$. The limit of detection and limit of quantification of azoxystrobin was found to be $5 \mathrm{ng} \mathrm{g}^{-1}$ and $10 \mathrm{ng} \mathrm{g}^{-1}$, respectively. The method was found to be accurate and reproducible. The recovery of azoxystrobin from grapes and soils fortified at $0.01,0.10$ and $1.00 \mu \mathrm{g} \mathrm{g}^{-1}$ levels were found to be $89.25 \pm 2.77,92.66 \pm 5.15$, $89.08 \pm 3.14$, and $98.25 \pm 1.72,98.98 \pm 1.52,97.84 \pm$ 5.39 per cent, respectively.
The average initial deposits on grape berries at different locations following application of azoxystrobin varied from 0.83 to $0.88 \mu \mathrm{g} \mathrm{g}^{-1}$ and $1.13-1.71 \mu \mathrm{g} \mathrm{g}^{-1}$ at recommended and double the recommended dose, respectively (Table 2). Slight variations in initial deposits were observed in the recommended and double the recommended dose. This variation may be due to difference in plant growth related to the varieties of grapes and locations. The residues of azoxystrobin dissipated with time. In the 7-day samples 0.62 and $1.19 \mu \mathrm{g} \mathrm{g}^{-1}$ residues of azoxystrobin were detected at recommended and double the recommended dose, respectively, which is approximately loss of 45-68\%. In the 14-day samples 0.41 and $0.93 \mu \mathrm{g} \mathrm{g}^{-1}$ residues of azoxystrobin were detected, amounting to a loss of 59-83\% (Table 3). After 21 days, no residues were detected at the recommended rate of application; whereas, $0.03-0.07 \mu \mathrm{g} \mathrm{g}^{-1}$ residues of azoxystrobin were detected at double the recommended dose. The residue was found to be less than the prescribed MRL (0.5 $\left.\mathrm{mg} \mathrm{kg}^{-1}\right)$.

The residue data was subjected to rate kinetics and halflife was calculated. It followed first order rate kinetics. The calculated half life, waiting period, regression equation and correlation coefficient of azoxystrobin at recommended and double the recommended dose is given in Table 3 . The half life varied from 5.4 to 11.2 days with significant correlation coefficient $(\mathrm{r}>0.97)$.

The rate of dissipation $\left(\mathrm{T}_{1 / 2}\right)$ of azoxystrobin was 5.4-8.9 days at recommended dose $\left(150 \mathrm{~g}\right.$ ai ha $\left.{ }^{-1}\right)$ and 7.0-10.4 days at double the recommended dose $\left(300 \mathrm{~g}\right.$ ai ha $\left.{ }^{-1}\right)$. Dissipation of azoxystrobin in grape berries at various locations in India followed the order Maharashtra $\left(\mathrm{T}_{1 / 2} 5.4\right.$ days $)>$ Tamil Nadu ( $\mathrm{T}_{1 / 2} 6.1$ days $)$ and Karnataka ( $\mathrm{T}_{1 / 2} 7.0$ days) at recommended rate of application (Table 4). The difference in dissipation at various locations may be due to the different weather conditions and

Table 2 Persistence of azoxystrobin in grape berries at three selected locations in India

\begin{tabular}{|c|c|c|c|c|c|c|}
\hline \multirow[t]{3}{*}{ Location } & \multirow[t]{3}{*}{ Dose $\left(\mathrm{g}\right.$ ai ha $\left.{ }^{-1}\right)$} & \multicolumn{5}{|c|}{ Residues $\left(\mu \mathrm{g} \mathrm{g}^{-1}\right)$} \\
\hline & & \multicolumn{5}{|c|}{ Days after application } \\
\hline & & 0 & 3 & 7 & 14 & 21 \\
\hline \multirow[t]{2}{*}{ Karnataka } & 150 & $0.83 \pm 0.05^{\mathrm{a}}$ & $0.62 \pm 0.02(29.5)^{\mathrm{b}}$ & $0.41 \pm 0.03$ & $0.27 \pm 0.02(83.0)$ & ND (100) \\
\hline & 300 & $1.71 \pm 0.12$ & $1.19 \pm 0.04(11.5)$ & $0.93 \pm 0.04(45.2)$ & $0.68 \pm 0.03(59.2)$ & $0.03 \pm 0.01$ \\
\hline \multirow[t]{2}{*}{ Maharashtra } & 150 & $0.88 \pm 0.11$ & $0.62 \pm 0.02(25.3)$ & $0.28 \pm 0.05(50.6)$ & $0.15 \pm 0.02(67.5)$ & ND (100) \\
\hline & 300 & $1.57 \pm 0.10$ & $1.39 \pm 0.30(30.4)$ & $0.86 \pm 0.01$ & $0.64 \pm 0.10(60.2)$ & $0.05 \pm 0.01$ \\
\hline \multirow[t]{2}{*}{ Tamil Nadu } & 150 & $0.86 \pm 0.06$ & $0.66 \pm 0.03$ & $0.38 \pm 0.02(55.8)$ & $0.18 \pm 0.03(79.1)$ & ND (100) \\
\hline & 300 & $1.13 \pm 0.11$ & $0.81 \pm 0.04$ & $0.52 \pm 0.04$ & $0.28 \pm 0.03(75.2)$ & $0.07 \pm 0.01$ \\
\hline
\end{tabular}


Table 3 Calculated half life, waiting period, regression equation and correlation coefficient (r) of azoxystrobin when applied at recommended and double dose

\begin{tabular}{|c|c|c|c|c|c|}
\hline Location & 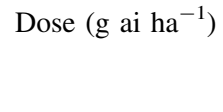 & Regression equation $[\mathrm{Y}=\mathrm{a}-\mathrm{bX}]$ & $\mathrm{r}$ & Half-life (days) & $\begin{array}{l}\text { Waiting } \\
\text { period } \\
\text { (days) }\end{array}$ \\
\hline \multirow[t]{2}{*}{ Karnataka } & 150 & $\mathrm{Y}=-0.102-0.034 \mathrm{X}$ & 0.99 & 7.0 & 5.9 \\
\hline & 300 & $\mathrm{Y}=-0.079-0.043 \mathrm{X}$ & 0.97 & 8.9 & 8.8 \\
\hline \multirow[t]{2}{*}{ Maharashtra } & 150 & $\mathrm{Y}=-0.072-0.056 \mathrm{X}$ & 0.98 & 5.4 & 4.1 \\
\hline & 300 & $\mathrm{Y}=-0.195-0.029 \mathrm{X}$ & 0.97 & 10.4 & 17.1 \\
\hline \multirow[t]{2}{*}{ Tamil Nadu } & 150 & $\mathrm{Y}=-0.055-0.049 \mathrm{X}$ & 0.99 & 6.1 & 5.0 \\
\hline & 300 & $\mathrm{Y}=-0.040-0.043 \mathrm{X}$ & 0.99 & 7.0 & 7.9 \\
\hline
\end{tabular}

$\mathrm{MRL}=0.5 \mathrm{mg} \mathrm{kg}^{-1}$

Table 4 Dietary exposure to azoxystrobin through grapes

\begin{tabular}{|c|c|c|c|c|c|c|}
\hline \multirow[t]{3}{*}{ Location } & \multirow[t]{3}{*}{ Dose $\left(\mathrm{g}\right.$ ai ha $\left.{ }^{-1}\right)$} & \multicolumn{5}{|c|}{ Dietary exposure (mg per person per day) } \\
\hline & & \multicolumn{5}{|c|}{ Days after application } \\
\hline & & 0 & 3 & 7 & 14 & 21 \\
\hline \multirow[t]{2}{*}{ Karnataka } & 150 & $0.083(0.92)^{\mathrm{a}}$ & $0.062(0.68)$ & $0.041(0.46)$ & $0.027(0.30)$ & - \\
\hline & 300 & $0.171(1.90)$ & $0.119(1.32)$ & $0.093(1.03)$ & $0.068(0.75)$ & $0.003(0.03)$ \\
\hline \multirow[t]{2}{*}{ Maharashtra } & 150 & $0.088(0.98)$ & $0.062(0.69)$ & $0.028(0.31)$ & $0.015(0.17)$ & - \\
\hline & 300 & $0.157(1.74)$ & $0.139(1.54)$ & $0.086(0.96)$ & $0.064(0.71)$ & $0.005(0.06)$ \\
\hline \multirow[t]{2}{*}{ Tamil Nadu } & 150 & $0.086(0.96)$ & $0.066(0.73)$ & $0.038(0.42)$ & $0.018(0.20)$ & - \\
\hline & 300 & $0.113(1.26)$ & $0.081(0.90)$ & $0.052(0.58)$ & $0.028(0.31)$ & $0.007(0.08)$ \\
\hline
\end{tabular}

${ }^{\mathrm{a}}$ Figures in parentheses denotes \% of ADI per person

the growth parameters of different varieties of grapes grown at these locations. A waiting period varying from 4.0 to 5.9 days and 7.9 to 17.1 days was calculated for the recommended and double the recommended rate of application, respectively. Based on these data a waiting period (Post harvest interval, PHI) of 7 days for the recommended rate of application on grapes is suggested under Indian climatic conditions.

The dietary exposure studies were conducted based on residues present in grapes at different sampling intervals. The ADI value of $0.18 \mathrm{mg} \mathrm{kg}$ body weight for azoxystrobin was taken from literature (FAO 2008). Similarly, average per capita consumption of fruits (grapes) was taken as $100 \mathrm{~g}$ per person per day (FAO 2009). Maximum permissible intake (MPI) or ADI per person was calculated by multiplying ADI $\times$ average body weight $(50 \mathrm{~kg})$ and worked out to be $9 \mathrm{mg}$ azoxystrobin per person per day. The dietary exposure was calculated by multiplying residue level at particular day sample with average per capita consumption of fruits. The maximum dietary exposure values ranged from 0.083 to $0.171 \mathrm{mg}$ per person per day for initial deposits (0 day samples) which accounts for $0.92-1.90 \%$ of permissible intake of $9 \mu \mathrm{g}$ azoxystrobin per person per day (Table 4). Since dietary exposure never exceeded $2 \%$ of ADI, the grape berries could be considered safe for human consumption on the day of application even at double the recommended rate of application.

The residues of azoxystrobin were estimated in field soil following foliar application on grape vines. The initial deposits in the field soil varied from 0.55 to $0.65 \mu \mathrm{g} \mathrm{g}^{-1}$ and 0.86 to $0.99 \mu \mathrm{g} \mathrm{g}^{-1}$ following application of azoxystrobin@150 $\mathrm{g} \mathrm{ai} \mathrm{ha}^{-1}$ and $300 \mathrm{~g}$ ai ha ${ }^{-1}$, respectively (Table 5). The residues dissipated with time, after 7 days of application $0.19-0.29 \mu \mathrm{g} \mathrm{g}^{-1}$ residues were detected at the recommended rate, which amounts for $53-70 \%$ loss. After 14 days of application, $0.14-0.20 \mu \mathrm{g} \mathrm{g}^{-1}$ residues were detected at the recommended rate of application. However, no residues of azoxystrobin were detected after 21 days of application. The dissipation of azoxystrobin followed first order rate kinetics $(r>0.8)$. The estimated average half-life was found to be 7.5 days at recommended dose and 8.1 day at double the recommended dose. Similarly, there was not much difference in rate of dissipation of azoxystrobin from soils collected from three different locations. The average half-life was 7.5, 7.9 and 8.1 days in soils collected from Karnataka, Maharashtra and Tamil Nadu, respectively. 
Table 5 Persistence of azoxystrobin in grape field soils (after 5th spray) at three locations with calculated half life

\begin{tabular}{|c|c|c|c|c|c|c|c|}
\hline \multirow[t]{3}{*}{ Location } & \multirow[t]{3}{*}{ Dose $\left(\mathrm{g}\right.$ ai ha $\left.{ }^{-1}\right)$} & \multicolumn{5}{|c|}{ Residues $\left(\mu \mathrm{g} \mathrm{g}^{-1}\right)$} & \multirow[t]{3}{*}{ Half-life (days) } \\
\hline & & \multicolumn{5}{|c|}{ Days after application } & \\
\hline & & 0 & 3 & 7 & 14 & 21 & \\
\hline \multirow[t]{2}{*}{ Karnataka } & 150 & $0.65 \pm 0.05^{\mathrm{a}}$ & $0.45 \pm 0.06$ & $0.29 \pm 0.04$ & $0.16 \pm 0.02$ & ND & 7.0 \\
\hline & 300 & $0.88 \pm 0.02$ & $0.59 \pm 0.03$ & $0.39 \pm 0.04$ & $0.25 \pm 0.01$ & ND & 7.9 \\
\hline \multirow[t]{2}{*}{ Maharashtra } & 150 & $0.55 \pm 0.01$ & $0.23 \pm 0.01$ & $0.19 \pm 0.01$ & $0.14 \pm 0.02$ & ND & 7.6 \\
\hline & 300 & $0.86 \pm 0.03$ & $0.38 \pm 0.03$ & $0.26 \pm 0.03$ & $0.21 \pm 0.03$ & ND & 8.1 \\
\hline \multirow[t]{2}{*}{ Tamil Nadu } & 150 & $0.59 \pm 0.05$ & $0.42 \pm 0.04$ & $0.28 \pm 0.03$ & $0.20 \pm 0.01$ & ND & 7.1 \\
\hline & 300 & $0.99 \pm 0.11$ & $0.70 \pm 0.03$ & $0.45 \pm 0.03$ & $0.25 \pm 0.02$ & ND & 9.1 \\
\hline
\end{tabular}

$N D$ not detectable, Limit of Quantification- $0.01 \mu \mathrm{g} \mathrm{g}^{-1}$

${ }^{\text {a }}$ Standard deviation

The residues of azoxystrobin detected in grape berries from three different locations subjected to dietary exposure studies revealed its safety to the consumers. However, for regulatory purposes, a waiting period or PHI (Post harvest intervals) of 7 days has been recommended. No buildup of azoxystrobin residues was observed in the field soil. Thus, azoxystrobin could be recommended for use for the management of diseases in grapes.

The study suggests that when azoxystrobin was applied at the recommended and double the recommended rate of application, no residues were detected at harvest in grape berries. Thus, the application of azoxystrobin was found to be safe from the consumer's point of view as well as for export purposes.

Acknowledgments The financial assistance received from $\mathrm{M} / \mathrm{s}$ Rallis India Limited, Bangalore (India) is gratefully acknowledged.

Open Access This article is distributed under the terms of the Creative Commons Attribution Noncommercial License which permits any noncommercial use, distribution, and reproduction in any medium, provided the original author(s) and source are credited.

\section{References}

Anand T, Angannan C, Kuttalam SP, Senthilraja G, Raguchander T, Samiyappan R (2008) Effectiveness of azoxystrobin in the control of Erysiphe cichoracearum and Pseudoperonospora cubensis on cucumber. J Plant Protect Res 48:147-159

Anonymous (2009) List of pesticides for use in grapes approved by the CIB, Ministry of Agriculture, Govt. of India, New Delhi under the Insecticides Act 1968. http://nrcgrapes.nic.in/zipfiles/ Pesticide.List.pdf

APEDA (2009) India exports statistics. http://tradejunction.apeda. com/ProdGallery/PrdProfile.aspx ?prdc $=0205 \&$ prdn $=$ Fresh $\% 20$ Grapes

Bartlett DW, Clough JM, Godwin JR, Hall AA, Hamer M, ParrDobrzanski B (2002) Review: the strobilurin fungicides. Pest Manag Sci 58:649-662

Cabras P, Angioni A (2000) Pesticide residues in grapes, wine and their processing products. J Agric Food Chem 48:967-973

Cabras P, Angioni A, Garau VL, Pirisi FM, Espinoza J, Mendoza A, Cabitza F, Pala M, Brandolini V (1998) Fate of azoxystrobin, fluazinam, kresoxim-methyl, mepanipyrim, and tetraconazole from vine to wine. J Agric Food Chem 46:3249-3251

FAO (2008) Evaluation of data for acceptable daily intake and acute dietary intake for humans, maximum residue levels and supervised trial median residue values: Azoxystrobin plant production and protection paper, 193, pp 55-60

FAO (2009) Market profile on tropical fruits in India. IV. Apparent consumption www.fao.org/es/esc/common/ecg/225/en/India_web. pdf

Lentzarizos C, Avramides EJ, Kokkinaki K (2006) Residues of azoxystrobin from grapes to raisins. J Agric Food Chem 54:138141

Pearson RC, Goheen AC (1994) Compendium of Grape Diseases. American Phytopathological Society Press, St. Paul, MN

Sendhilvel V, Raghuchander T, Nakkeran S, Amutha G, Marimuthu T (2004) Bioefficacy of azoxystrobin against downy mildew of grapewine. Pestology 18:44-51 